\title{
Why did IL-23p19 inhibition fail in AS: a tale of tissues, trials or translation?
}

\author{
Stefan Siebert, Neal L Millar, lain B McInnes
}

Clinical trials investigating biologic immune targeting therapeutics should deliver insight regardless of direction of the primary clinical outcome. Given the remarkable specificity of the 'molecular scalpels' now consequent upon the pharmacologic biologic revolution, it is imperative to learn lessons, particularly from those studies whose outcomes challenge pathogenetic wisdom. In this context, progress in understanding and treatment of the spondyloarthritides (SpA) and related extra-articular manifestations, especially psoriasis and inflammatory bowel disease (IBD), has been remarkable in the last decade. This group of phenotypically related, but still rather heterogeneous conditions share common genetic and pathogenetic features, leading to the notion that common clinical responses across the SpA spectrum should arise from specific immune-targeted interventions. This notion may shortly be disabused.

Whereas initial therapeutic advances in $\mathrm{SpA}$ comprised adoption of tumour necrosis factor (TNF) inhibitors from rheumatoid arthritis, major recent therapeutic breakthroughs followed identification of a substantial role for the IL-23/IL-17 pathway in pathogenesis. These studies integrated insights from a composite of genome-wide association studies (GWASs), postfunctional genomic studies, tissue analyses and a variety of preclinical models. Advances have been most marked in psoriasis with 'PASI100' response rates of around $50 \%-70 \%$ following IL-17A or IL-23p19 inhibition. ${ }^{1-5}$ Subsequently, IL-12/23p40, IL-23p19 and IL-17A inhibitors demonstrated efficacy in psoriatic arthritis (PsA), although this has been somewhat less penetrant in terms of high-hurdle responses. ${ }^{6-11}$ The IL-17A inhibitor, secukinumab, has recently also been shown to be efficacious in patients with active ankylosing spondylitis (AS). ${ }^{12}$ Studies of IL-23 inhibition for the treatment of AS were commenced based on

Institute of Infection Immunity and Inflammation, University of Glasgow, Glasgow, UK

Correspondence to Professor lain B McInnes, Institute of Infection Immunity and Inflammation, University of Glasgow, Glasgow G128QQ, UK; iain.mcinnes@glasgow.ac.uk this suggestive preclinical and human data resource.

In Annals of the Rheumatic Diseases, Baeten and colleagues present a phase II clinical trial evaluating risankizumab, a humanised monoclonal antibody targeting the p19 subunit of IL-23, in patients with active AS. ${ }^{13}$ The authors and editors should be congratulated for bringing these data into the public domain to advance our understanding of underlying disease pathogenesis. The trial evaluated three doses of risankizumab compared with placebo in biologic-naive patients with active AS. Risankizumab doses were

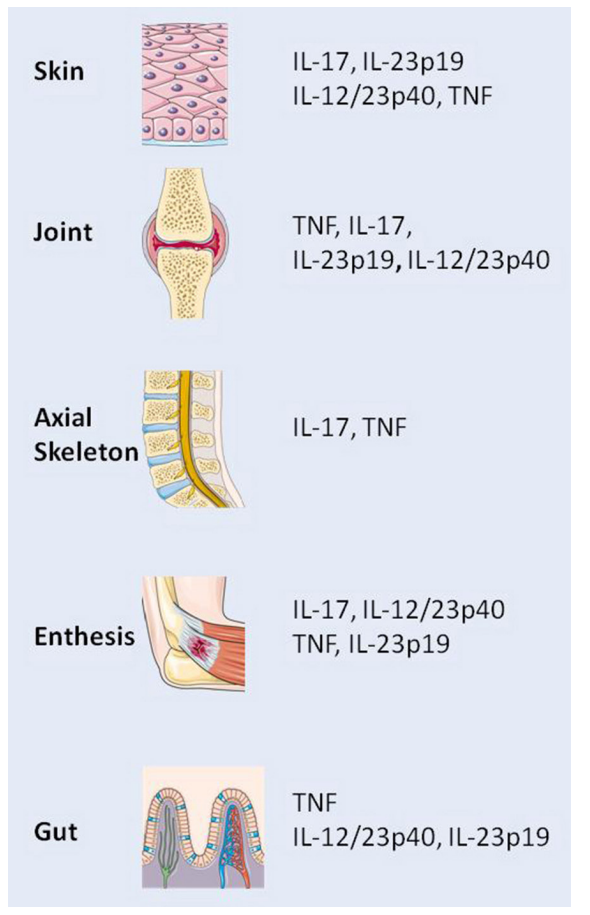

Figure 1 Proposed notional emerging tissue cytokine hierarchy based on current clinical trial data. There is now increasing evidence suggesting that different cytokines may enjoy distinct hierarchical roles in tissues across the spondyloarthritis spectrum. This figure highlights those pathways with demonstrable effects in each discrete tissues against those in which clinical responses were not observed. In the absence of formal head-to-head studies, these comparators should be taken as potential rather than proven. Future analyses are now required to ascribe formal within-tissue hierarchies. selected based on data from a phase I study in psoriasis and were shown to have superior efficacy to the p40 IL-23 inhibitor ustekinumab in a subsequent phase II trial in psoriasis. ${ }^{5}$ However, the current study of risankizumab in patients with active AS failed to meet the primary endpoint (ASAS40 at week 12) and demonstrated no convincing improvements in clinical or MRI outcomes compared with placebo, despite a dose-dependent reduction in $\mathrm{C}$ reactive protein with risankizumab.

While these results may initially appear surprising in light of the efficacy of IL-17A inhibition in AS, the study by Baeten et al should be more wisely considered in the wider context of increasingly tissue-discrete results for IL-23/IL-17 inhibition across the SpA spectrum (figure 1). In cutaneous psoriasis, the dominant role of the IL-23/IL-17 pathway is firmly established and has led to impressive results with an increasing array of inhibitors of these cytokines reaching the clinic. In PsA, while IL-17A and IL-23 (both p40 and p19) inhibition has demonstrated efficacy for synovial and entheseal disease, the results are more modest and have not met the high hurdles seen in cutaneous psoriasis. A study using paired biopsies of skin and synovium in patients with PsA reported a dominant IL-17 gene signature in lesional skin compared with a stronger TNF signature in synovium ${ }^{14}$ perhaps suggesting that the clinical trial data may have pathogenetic correlates. In Crohn's disease, IL-23 inhibition with p40 (ustekinumab) and p19 (risankizumab) inhibitors has demonstrated efficacy in phase II/III studies. ${ }^{15} 16$ In contrast, a phase II study of IL-17A inhibition with secukinumab did not meet its primary outcome and a phase II study of brodalumab, an IL-17RA inhibitor, was prematurely stopped, with numerical worsening of Crohn's disease in the treatment groups for both studies. ${ }^{17} 18$ Therefore, while preclinical data suggested a role for both IL-23 and IL-17A in the pathogenesis of Crohn's disease, inhibition of these cytokines led to divergent results in clinical trials. Indeed, it has been suggested subsequently that IL-17A may have pathogenic and protective roles in the gut, with IL-23-independent IL-17A production required for regulation of intestinal epithelial permeability via the tight junction protein occludin. ${ }^{19}$ More recently, the IL-17F pathway has also emerged as having distinct mucosal biologic features. ${ }^{20}$ Interestingly, AS has a strong association with IBD, with $15 \%$ of patients developing overt IBD and up to $60 \%$ exhibiting evidence of underlying subclinical microscopic colitis, which has 


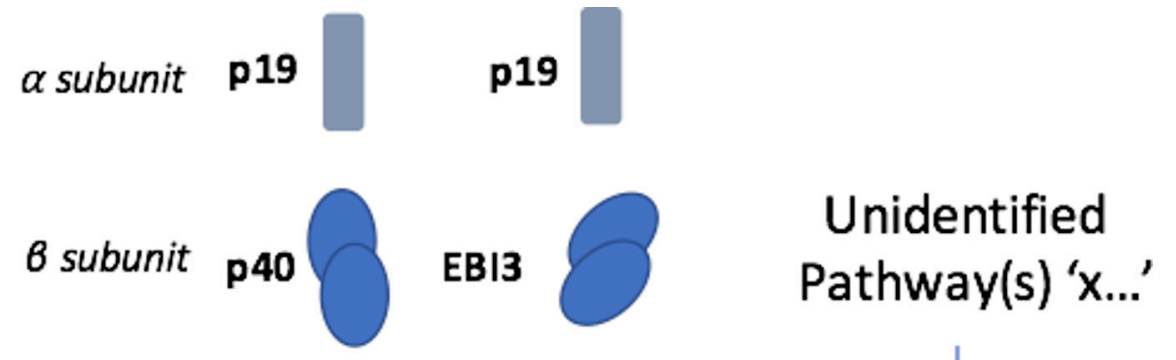

IL-23 p19/p40 IL-39 p19/EB|3

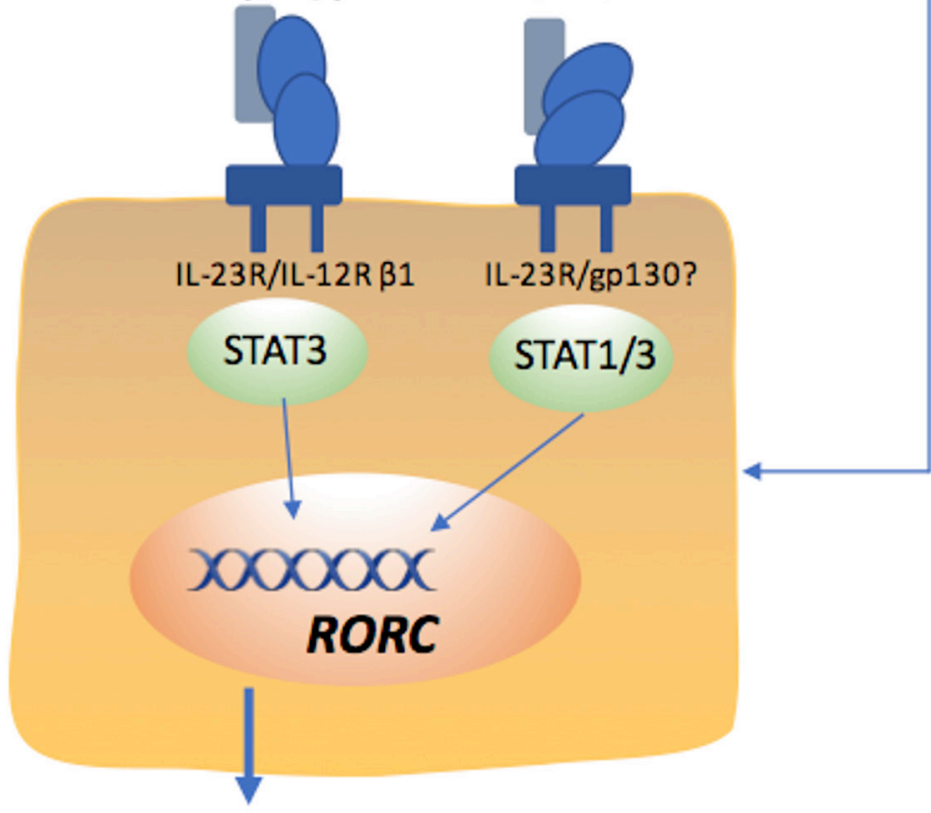

\section{IL-17A \\ IL-17F \\ IL-23R}

Figure 2 Potential cytokine pathways driving IL-17 responses in spondyloarthritis.

been proposed to contribute to the pathogenesis of AS. ${ }^{2122}$ In light of the data from the Crohn's disease trial programme, one might even have anticipated that IL-23 inhibition would be more effective than IL-17 inhibition in AS due to underlying IBD or subclinical colitis.

Taken together, clinical trial data have fundamentally challenged the notion that the pathogenic pathways driving disease in the tissues impacted in the SpA spectrum are truly common. We propose that each component tissue will comprise a specific immunologic pathology programme that reflects its evolutionary imperative for host defence, and as such therapeutic interventions must embrace such teleologic immunologic reality.

Could this be a trial design artefact? Several factors suggest that Baeten et al accurately describe the biological role of not be readily ignored. The phase III trials in AS and non-radiographic axSpA of the IL-12/IL-23 inhibitor ustekinumab were recently terminated for not meeting key efficacy endpoints (ClinicalTrials.gov NCT02438787 and NCT02407223), despite a small open-label study suggesting efficacy in 20 patients with AS. ${ }^{23}$ Taken together, these data suggest that, in contrast to IL-17A blockade, IL-23 inhibition is not an effective strategy for the treatment of AS, which raises the critical question-why?

The preclinical evidence supporting IL-23p19 blockade in AS was robust per current standards of 'a priori' proof-ofconcept (POC). As noted above, GWASs clearly implicate the IL-23R pathway in disease risk and progression. The use of minicircle DNA technology to express IL-23 in the hepatocytes of B10.RIII mice resulted in a destructive polyarthritis that was found to be independent of $\mathrm{CD}^{+}{ }^{+} \mathrm{T}$ cells ${ }^{24}$ while a further animal study ${ }^{25}$ using similar technology revealed that systemic expression of IL-23 in normal mice was sufficient to induce the major features of $\mathrm{SpA}$ (enthesitis, sacroiliitis and aortic root inflammation), putatively through activation of a novel population of innate $\mathrm{CD}^{+}, \mathrm{CD}^{-} \mathrm{CD}^{-}$and retinoic acid receptor-related orphan nuclear receptor $\gamma t$ (ROR $\gamma \mathrm{t}$ )-positive $\mathrm{T}$ cells located in the entheses of these mice. While the precise source of IL-23 was not identified, a further study suggested that these cells were tissue-resident $\mathrm{V} \gamma 6^{+} \gamma \delta \mathrm{T}$ cells ${ }^{26}$ promoting bone growth through IL- $17^{27}$ and were therefore a putative pathogenic cell population linking IL-23-induced inflammation to bone growth in the enthesis. Follow-on human studies revealed the number of $\gamma \delta \mathrm{T}$ cells that produce IL-17 and express IL-23R was elevated in peripheral blood in people with $\mathrm{AS}^{28}$ Interestingly, only one study ${ }^{29}$ has confirmed the presence of $\mathrm{CD} 4^{-} \mathrm{CD} 8^{-}$ $\mathrm{T}$ cells in human entheseal digests. Further examination of T-cell subsets indicated that a high proportion of these cells were likely $\gamma / \delta \mathrm{T}$ cells, but no functional analysis of these human subsets was undertaken. Human tissue analysis ${ }^{30}$ revealed a significantly higher incidence of IL- $23^{+}$ cells in patients with AS with the majority of IL-17-producing cells comprising myeloperoxidase-positive and CD15-positive neutrophils rather than $\mathrm{CD} 3^{+} \mathrm{T}$ cells, suggesting that IL-17-producing cells other than Th17 cells are relevant in local inflammation in this population. There is evidence to support IL-23-independent induction of IL-17 from $\gamma \delta \mathrm{T}$ cells and innate lymphoid cells. ${ }^{31}$ Thus, given this 
disparate cell expression profile between mouse and human studies, it is plausible (but not yet proven) that IL-23-independent sources of IL-17 (eg, via ILCs, CD $15^{+}$neutrophils) are of pathogenetic importance in driving disease chronicity in AS. Furthermore, given the presumed central role of ROR $\gamma t$ as a 'master' transcription factor of the type 17 response in entheseal disease and recent evidence that it acts in an IL-23 independent fashion, ${ }^{19}$ we contend that there could be a molecular argument that p19 inhibition alone will prove insufficient to effectively target the type 17 immune response evident in the axial component of the SpA spectrum.

While the IL-12 family cytokines have pleiotropic functions with parallel unique characteristics, much attention initially focused on the p19 subunit combination with the p40 subunit forming IL-23(p19/40). Subsequent signalling was considered pivotal through the IL-23R/ IL-12R $\beta 1$ receptors with downstream STAT3 proposed in autoimmune diseases, including AS. ${ }^{32}$ Although four bona fide members have thus far been described, promiscuous chain-pairing between alpha (IL-23p19， IL-27p28， IL-12/IL-35p35) and beta (IL-12/IL-23p40, IL-27/ IL-35Ebi3) subunits predicts six possible heterodimeric IL-12 family cytokines. ${ }^{33}$ Indeed, emerging evidence has highlighted that the p19 and EBi3 form, a novel p19/ Ebi3 heterodimer termed IL-39, mediates inflammation in lupus-like MRL/lpr mice $^{34}$ and importantly anti-mouse IL-39 polyclonal antibodies ameliorate autoimmune symptoms in lupus-like mice. ${ }^{35} \mathrm{~A}$ similar association between p19 and EBI3 was suggested in damaged keratinocytes, possibly contributing to wound healing by dampening inflammatory responses ${ }^{36}$ linking stromal and immune responses of the p19 subunit. Thus, given increasing evidence that local damage may provide a trigger for $\mathrm{SpA},{ }^{37}$ the intriguing heterodimerisation of the p19 subunit towards IL-39 provides a plausible, potential alternate mechanism driving pathology . More studies around the role of p19 in this context, and indeed how p19 inhibiting antibodies modify such biology, will be important in axSpA. Moreover, it is becoming apparent that $\mathrm{T}_{\mathrm{H}} 17$ cells are not homogeneous, with a large body of work indicating an inherent instability of $\mathrm{T}_{\mathrm{H}} 17$ cell populations. ${ }^{38}$ Data concerning the role of IL-23 in the generation of non- $\mathrm{T}_{\mathrm{H}} 17$ Treg cells are conflicting. Some studies suggest that IL-23 promotes the accumulation of Treg cells in the gut, ${ }^{39}$ which are probably non- $\mathrm{T}_{\mathrm{H}} 17$ Treg cells. ${ }^{40}$ Conversely, IL-23 promotes the stability of pathogenic $T_{H} 17$ cells through the transcription factor PR domain zinc finger protein 1 (PRDM1). ${ }^{41}$ These findings suggest that increased numbers of $\mathrm{T}_{\mathrm{H}} 17$ cells in patients with AS might not result from preferential differentiation of naive $\mathrm{T}$ cells with particular reference to early IL-23p19 expression, but rather through a reduced plasticity of mature $\mathrm{T}_{\mathrm{H}} 17$ cells. Thus more information as to the biology of IL-23 in the joint and GI mucosa is required. Having previously been relatively underinvestigated, the involvement of IL-17-producing CD8 ${ }^{+} \mathrm{T}$ cells ( $\mathrm{T}_{\mathrm{C}}$ cells) and innate lymphoid cells in autoimmune inflammation has now been documented in both humans and mice. ${ }^{42}$ In particular, recent data suggest enrichment of articular $\mathrm{T}_{\mathrm{C}}$ cells across multiple SpA subtypes ${ }^{43}$ and identify a phenotypic signature for IL- $17^{+} \mathrm{CD} 8^{+} \mathrm{T}$ cells, consisting of type 17 and tissue-associated markers ${ }^{44}$ implicating such cells as important contributors to the pathogenesis of axSpA. How such cells relate to IL-23 biology is now also requires further investigation.

Taken together, established AS may have 'transitioned pathogenetically' to a mature type 17 phenotype, which is unresponsive to IL-23p19 blockade and other upstream treatment strategies (eg, IL-6 inhibition ${ }^{45}$ ) that might otherwise modulate type 17 cell differentiation. As a consequence, at a molecular level, the IL-23p19 subunit appears not the only regulatory agent for targeting the type 17 response in AS, and, by corollary, neutralising this upstream molecule seems to be less effective than specifically targeting IL-17A in AS (figure 2). The identity of additional drivers to the IL-17 response and indeed other effector pathologic pathways should now be sought.

The apparent failure of IL-23p19 inhibition in AS serves further as salutary reminder of the complexity of chronic polygenic human inflammatory diseases but, paradoxically, helps advance our understanding of these diseases by redefining our understanding of the importance of a pathway within the pathogenetic hierarchy. Preclinical modelling, even supported by state-of-the-art genetic and postgenomic functional studies, remain imperfect in their predictive use. With the expansion of therapeutic novel modes of action, the next decade will offer unparalleled opportunities to build 'new knowledge on old' as clinical trial datasets accrue; as such, we can build pathogenetic understanding based on truly human disease models. Thus, the importance of confirming apparently persuasivepreclinical results in humans remains key, while there remain lessons to be learnt about applying animal data to humans. Considering tissue-specific and time-specific cytokine responses and hierarchies when developing novel therapies would seem wise.

\section{Handling editor Josef S Smolen}

Contributors SS and NM contributed equally to the preparation of the article. SS, NM and IBM designed the article and selected the content and literature to be reviewed and interpreted.

Funding The authors have not declared a specific grant for this research from any funding agency in the public, commercial or not-for-profit sectors.

Competing interests SS has received honoraria or research funding to his University from Novartis, Celgene, Janssen, Pfizer, AbbVie, UCB and Boehringer Ingelheim. NM has received honoraria or research funding to his University from Novartis and Stryker. IBM has received honoraria or research funding to his University from Novartis, Celgene, Janssen, Pfizer, AbbVie, UCB and Boehringer Ingelheim.

Patient consent Not required.

Provenance and peer review Commissioned; externally peer reviewed.

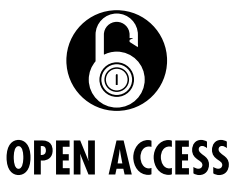

Open access This is an open access article distributed in accordance with the Creative Commons Attribution Non Commercial (CC BY-NC 4.0) license, which permits others to distribute, remix, adapt, build upon this work non-commercially, and license their derivative works on different terms, provided the original work is properly cited, appropriate credit is given, any changes made indicated, and the use is non-commercial. See: http:// creativecommons.org/licenses/by-nc/4.0/

(C) Author(s) (or their employer(s)) 2019. Re-use permitted under CC BY-NC. No commercial re-use. See rights and permissions. Published by BMJ.

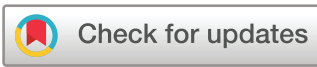

To cite Siebert S, Millar NL, McInnes IB. Ann Rheum Dis 2019;78:1015-1018.

Received 3 July 2018

Revised 27 July 2018

Accepted 27 July 2018

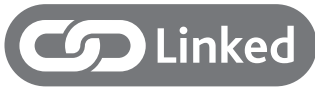

- http://dx.doi.org/10.1136/annrheumdis-2018213328

Ann Rheum Dis 2019;78:1015-1018.

doi:10.1136/annrheumdis-2018-213654

\section{REFERENCES}

1. Langley RG, Elewski BE, Lebwohl M, et al. Secukinumab in plaque psoriasis - results of two phase 3 trials. N Engl J Med 2014;371:326-38.

2. Griffiths CE, Reich $\mathrm{K}$, Lebwohl M, et al. Comparison of ixekizumab with etanercept or placebo in moderateto-severe psoriasis (UNCOVER-2 and UNCOVER-3): results from two phase 3 randomised trials. Lancet 2015;386:541-51. 
3. Blauvelt A, Papp KA, Griffiths CE, et al. Efficacy and safety of guselkumab, an anti-interleukin-23 monoclonal antibody, compared with adalimumab for the continuous treatment of patients with moderate to severe psoriasis: results from the phase III, doubleblinded, placebo- and active comparator-controlled VOYAGE 1 trial. J Am Acad Dermatol 2017;76:405-17.

4. Reich K, Papp KA, Blauvelt A, et al. Tildrakizumab versus placebo or etanercept for chronic plaque psoriasis (reSURFACE 1 and reSURFACE 2): results from two randomised controlled, phase 3 trials. Lancet 2017:390:276-88

5. Papp KA, Blauvelt A, Bukhalo $M$, et al. Risankizumab versus ustekinumab for moderate-to-severe plaque psoriasis. N Eng/ J Med 2017;376:1551-60.

6. Mease PJ, McInnes IB, Kirkham B, et al. Secukinumab inhibition of interleukin-17a in patients with psoriatic arthritis. N Engl J Med 2015;373:1329-39.

7. Mclnnes IB, Mease PJ, Kirkham B, et al. Secukinumab, a human anti-interleukin-17A monoclonal antibody, in patients with psoriatic arthritis (FUTURE 2): a randomised, double-blind, placebo-controlled, phase 3 trial. Lancet 2015;386:1137-46.

8. Mease PJ, van der Heijde D, Ritchlin CT, et al. Ixekizumab, an interleukin-17A specific monoclonal antibody, for the treatment of biologic-naive patients with active psoriatic arthritis: results from the 24-week randomised, double-blind, placebo-controlled and active (adalimumab)-controlled period of the phase III trial SPIRIT-P1. Ann Rheum Dis 2017;76:79-87.

9. McInnes IB, Kavanaugh A, Gottlieb AB, et al. Efficacy and safety of ustekinumab in patients with active psoriatic arthritis: 1 year results of the phase 3 , multicentre, double-blind, placebo-controlled PSUMMIT 1 trial. Lancet 2013:382:780-9.

10. Ritchlin C, Rahman P, Kavanaugh A, et al. Efficacy and safety of the anti-IL-12/23 p40 monoclonal antibody, ustekinumab, in patients with active psoriatic arthritis despite conventional non-biological and biological anti-tumour necrosis factor therapy: 6-month and 1 -year results of the phase 3 , multicentre, doubleblind, placebo-controlled, randomised PSUMMIT 2 trial. Ann Rheum Dis 2014;73:990-9.

11. Mease PJ, Kellner H, Morita A. OP0307 Efficacy and safety of risankizumab, a selective il-23p19 inhibitor, in patients with active psoriatic arthritis over 24 weeks: results from a phase 2 trial. Ann Rheum Dis 2018:77:200-1.

12. Baeten D, Sieper J, Braun J. Measure 1 study group; measure 2 study group. Secukinumab, an interleukin17a inhibitor, in ankylosing spondylitis. N Engl J Med 2015;373:2534-48.

13. Baeten D, Østergaard M, Wei JC, et al. Risankizumab, an IL-23 inhibitor, for ankylosing spondylitis: results of a randomised, double-blind, placebo-controlled, proofof-concept, dose-finding phase 2 study. Ann Rheum Dis 2018;77:1295-302.

14. Belasco J, Louie JS, Gulati N, et al. Comparative genomic profiling of synovium versus skin lesions in psoriatic arthritis. Arthritis Rheumatol 2015:67:934-44.
15. Feagan BG, Sandborn WJ, Gasink C, et al. Ustekinumab as induction and maintenance therapy for Crohn's disease. N Engl J Med 2016;375:1946-60.

16. Feagan BG, Sandborn WJ, D'Haens G, et al Induction therapy with the selective interleukin-23 inhibitor risankizumab in patients with moderateto-severe Crohn's disease: a randomised, doubleblind, placebo-controlled phase 2 study. Lancet 2017;389:1699-709.

17. Hueber W, Sands BE, Lewitzky S, et al. Secukinumab, a human anti-IL-17A monoclonal antibody, for moderate to severe Crohn's disease: unexpected results of a randomised, double-blind placebo-controlled trial. Gut 2012;61:1693-700

18. Targan SR, Feagan B, Vermeire $S$, et al. A randomized, double-blind, placebo-controlled phase 2 study of brodalumab in patients with moderate-tosevere Crohn's disease. Am J Gastroenterol 2016:111:1599-607.

19. Lee JS, Tato CM, Joyce-Shaikh B, et al. Interleukin23 -independent il-17 production regulates intestinal epithelial permeability. Immunity 2015;43:727-38

20. Tang C, Kakuta S, Shimizu K, et al. Suppression of IL-17F, but not of IL-17A, provides protection against colitis by inducing $T_{\text {reg }}$ cells through modification of the intestinal microbiota. Nat Immunol 2018;19:755-65.

21. Jacques P, Van Praet L, Carron P, et al. Pathophysiology and role of the gastrointestinal system in spondyloarthritides. Rheum Dis Clin North Am 2012;38:569-82.

22. Van Praet L, Van den Bosch F, Mielants $H$, et al. Mucosal inflammation in spondylarthritides: past, present, and future. Curr Rheumatol Rep 2011;13:409-15.

23. Poddubnyy D, Hermann KG, Callhoff J, et al. Ustekinumab for the treatment of patients with active ankylosing spondylitis: results of a 28-week, prospective, open-label, proof-of-concept study (TOPAS). Ann Rheum Dis 2014;73:817-23.

24. Adamopoulos IE, Tessmer M, Chao CC, et al. IL-23 is critical for induction of arthritis, osteoclast formation, and maintenance of bone mass. J Immunol 2011:187:951-9.

25. Sherlock JP, Joyce-Shaikh B, Turner SP, et al. IL-23 induces spondyloarthropathy by acting on ROR- $\gamma \mathrm{t}+$ CD3+CD4-CD8- entheseal resident T cells. Nat Med 2012;18:1069-76.

26. Reinhardt A, Yevsa T, Worbs T, et al. Interleukin-23dependent $\gamma / \delta$ T cells produce interleukin-17 and accumulate in the enthesis, aortic valve, and ciliary body in mice. Arthritis Rheumatol 2016:68:2476-86.

27. Ono T, Okamoto K, Nakashima T, et al. IL-17-producing $\gamma \delta T$ cells enhance bone regeneration. Nat Commun 2016;7:10928.

28. Kenna TJ, Davidson SI, Duan R, et al. Enrichment of circulating interleukin-17-secreting interleukin-23 receptor-positive $\gamma / \delta$ T cells in patients with active ankylosing spondylitis. Arthritis Rheum 2012:64:1420-9.
29. Cuthbert RJ, Fragkakis EM, Dunsmuir R, et al. Brief report: group 3 innate lymphoid cells in human enthesis. Arthritis Rheumatol 2017;69:1816-22.

30. Appel H, Maier R, Bleil J, et al. In situ analysis of interleukin-23- and interleukin-12-positive cells in the spine of patients with ankylosing spondylitis. Arthritis Rheum 2013;65:1522-9.

31. Hasegawa E, Sonoda KH, Shichita T, et al. IL-23independent induction of IL-17 from $\gamma \delta \mathrm{T}$ cells and innate lymphoid cells promotes experimental intraocular neovascularization. J Immunol 2013; 190:1778-87.

32. Lubberts $E$. The IL-23-IL-17 axis in inflammatory arthritis. Nat Rev Rheumatol 2015;11:415-29.

33. Hasegawa H, Mizoguchi I, Chiba Y, et al. Expanding diversity in molecular structures and functions of the IL-6/IL-12 heterodimeric cytokine family. Front Immunol 2016;7:479.

34. Wang X, Wei Y, Xiao H, et al. A novel IL-23p19/Ebi3 (IL-39) cytokine mediates inflammation in lupus-like mice. Eur J Immunol 2016;46:1343-50.

35. Wang $X$, Zhang Y, Wang Z, et al. Anti-IL-39 (IL-23p19/ Ebi3) polyclonal antibodies ameliorate autoimmune symptoms in lupus-like mice. Mol Med Rep 2018;17:1660-6

36. Ramnath D, Tunny K, Hohenhaus DM, et al. TLR3 drives IRF6-dependent IL-23p19 expression and p19/EBI3 heterodimer formation in keratinocytes. Immuno/ Cell Biol 2015;93:771-9.

37. Van Mechelen M, Lories RJ. Microtrauma: no longer to be ignored in spondyloarthritis? Curr Opin Rheumatol 2016;28:176-80.

38. Agalioti T, Villablanca EJ, Huber $S$, et al. $T_{H} 17$ cell plasticity: the role of dendritic cells and molecular mechanisms. J Autoimmun 2018:87:50-60.

39. Maxwell JR, Zhang Y, Brown WA, et al. Differential roles for interleukin-23 and interleukin-17 in intestinal immunoregulation. Immunity 2015;43:739-50.

40. Ohnmacht C, Park JH, Cording S, et al. Mucosal immunology. The microbiota regulates type 2 immunity through roryt ${ }^{+}$T cells. Science 2015;349:989-93.

41. Jain R, Chen Y, Kanno Y, et al. Interleukin-23-induced transcription factor blimp-1 promotes pathogenicity of T helper 17 cells. Immunity 2016:44:131-42.

42. Srenathan U, Steel K, Taams LS. IL-17+ CD8+ T cells: differentiation, phenotype and role in inflammatory disease. Immunol Lett 2016;178:20-6.

43. Menon B, Gullick NJ, Walter GJ, et al. Interleukin$17+C D 8+T$ cells are enriched in the joints of patients with psoriatic arthritis and correlate with disease activity and joint damage progression. Arthritis Rheumatol 2014;66:1272-81.

44. Steel KJ, SY W, Srenathan U. 0016 Synovial IL-17+ CD8+ T cells are a pro-inflammatory tissue resident population enriched in spondyloarthritis. Ann Rheum Dis 2018;77:A8-9.

45. Sieper J, Braun J, Kay J, et al. Sarilumab for the treatment of ankylosing spondylitis: results of a phase II, randomised, double-blind, placebocontrolled study (ALIGN). Ann Rheum Dis 2015:74:1051-7. 